\begin{tabular}{|c|c|c|c|c|c|c|}
\hline Region & $\begin{array}{c}\text { Rocks } \\
\text { sampled }\end{array}$ & $\begin{array}{l}\text { Declina- } \\
\text { tion }\end{array}$ & $\begin{array}{c}\text { Inclina- } \\
\text { tion }\end{array}$ & $\lambda$ & $K$ & $N$ \\
\hline N. Yorks" & $\begin{array}{l}\text { Middle Lias } \\
\text {-Lower } \\
\text { Corallian. } \\
\text { Arenaceous } \\
\text { sediments }\end{array}$ & N. $3 \cdot 4^{\circ} \mathrm{E}$. & $+66 \cdot 0^{\circ}$ & $2 \cdot 6^{\circ}$ & $87 \cdot 5$ & 36 \\
\hline $\begin{array}{l}\text { Arizond } \\
\text { North and } \\
\text { South }\end{array}$ & $\begin{array}{l}\text { Kay nta Fm. } \\
\text { (Lr. Jur.) } \\
\text { Basalt lavas } \\
\text { of Victoria }\end{array}$ & N. $6 \cdot 9^{\circ} \mathrm{W}$. & $+43 \cdot 5^{\circ}$ & $9 \cdot 6^{\circ}$ & 50 & 6 \\
\hline & $\begin{array}{l}\text { Falls and } \\
\text { Bulawayo }\end{array}$ & N. $30^{\circ} \mathrm{W}$ & $-40 \cdot 3^{\circ}$ & $4 \cdot 6^{\circ}$ & $18 \cdot 7$ & 44 \\
\hline Tasmania & $\begin{array}{l}\text { Intrusive } \\
\text { dolerite sills }\end{array}$ & N. $35^{\circ} \mathrm{W}$. & $-85^{\circ}$ & - & - & 一 \\
\hline
\end{tabular}

* Full details to be published.

The critical test of whether continental drift has occurred or not obviously lies in a study of the palxomagnetism of rocks of the same age in different continents. In this context the Jurassic period is of great importance, and it is now possible to assemble data from four continents as in Table 1 with the relevant statistics ${ }^{2}$.

Although the arenaceous sediments of the British Jurassic are largely unsuitable for palæomagnetic work, being either too weak for measurement or unstable, there are sufficient which appear to be stable to give the results tabulated. Runcorn's rocks from Arizona fall in the same category, and his results, which are based on a few specimens, must be regarded with caution.

The Rhodesian basalt lavas were collected from the Bulawayo area and from the Victoria Falls, where fresh material was obtained from the second gorge with the aid of Dr. G. Bond. The basalts following above the Triassic Forest Sandstone are generally considered of lower Jurassic age. The position of the pole in the northern hemisphere (lying in Hudson Bay) is in latitude $61^{\circ} \mathrm{N}$., longitude $76^{\circ} \mathrm{W}$. Irving ${ }^{3}$ carried out an extensive study of the intrusive dolerite sills of Tasmania. These sills, while certainly of Mesozoic age, have not been proved conclusively to be of Jurassic age. The ancient pole position, according to Irving, lay in latitude $50^{\circ} \mathrm{N}$., longitude $23^{\circ} \mathrm{W}$.

Thus it is clear that, while Britain in Jurassic times must be regarded as having approximately the same position as at present relative to the pole (the present pole lying within the circle of confidence of the Jurassic results), and the movement of America is not significant, it is equally clear that this is not the case in the southern hemisphere. The Rhodesian lavas indicate a movement of about 2,000 miles, and the Tasmanian results a movement of about 2,800 miles.

The inevitable conclusion is that continental drift must be accepted if the assumption of the coincidence of the axial dipole field with the rotational axis is accepted ${ }^{4}$. More exact dating of the time of drift and the relative positions of the continental blocks must depend on the more detailed work at present in hand in Great Britain, South Africa and Australia.

Department of Physics,

$$
\text { A. E. M. NAIRN }
$$

King's College,

Neweastle upon Tyne. July 3.

${ }^{1}$ Runcorn, S. K., Proc. Can. Geol. Assoc. (in the press).

${ }^{2}$ Fisher, R. A., Proc. Roy. Soc., A, 217, 295 (1953).

${ }^{3}$ Irving, E., Geophysica, 33 (1956).

'Runcorn, S. K., Trans. Amer. Geophys. Un., 35, 49 (1954).

\section{A Statistical Information Theory of Visual Thresholds}

IN their recent letter on this subject Gregory and Cane" state that "perhaps other threshold and summation phenomena may be described in terms of statistical information available in neural information channels". A survey of available data on the relationship between the Weber-Fechner fraction $\Delta I / I$ and stimulus area $A$ certainly supports this contention ${ }^{2}$.

Gregory and Cane make the assumption that the number of independent observations $n$ is proportional to the stimulus area $A$. Admittedly this is the simplest assumption; but there would seem to be good reasons for believing that the number of independent observations would more closely approximate the number of nerve fibres, $f$, operating in the area $A$, and $f$ is certainly not proportional to $A$ except perhaps for a limited range of areas in the fovea. If $f$ is the correct estimate of the number of independent observations, $\Delta I / I$ should be proportional to $1 / \sqrt{ } f$. Using data on the variation of visual acuity across the retina to provide an estimate of $f, \Delta I / I$ is in fact proportional to $1 / \sqrt{ } f$ to a good approximation, over the wide range of stimulus areas from $10^{\prime}$ diameter to $40^{\circ}$ diameter. There is some tendency for $\Delta I / I$ to be larger than predicted at very small field sizes, where eye-movements are probably a complicating factor, and at very large field sizes, where there is probably mental difficulty in utilizing simultaneously all the information supplied. If $\Delta I / I$ is plotted against $1 / \sqrt{ } A$ the results for field sizes up to about $2^{\circ}$ are similar; but those for larger field sizes are markedly worse. Thus, for a field size of $36^{\circ}$, using $1 / \sqrt{ } f$ the predicted value of $\Delta I / I$ is about half the actual value, but using $1 / \sqrt{ } A$ the predicted value is about one-ninth of the actual value.

This type of statistical approach is very useful in tackling visual problems of this nature, and if certain assumptions are made it can lead to far-reaching conclusions. For example, if it is assumed that

$$
N=f_{1}(c) \cdot f_{2}(I)
$$

where $N$ is the magnitude of the physiological response evoked by a stimulus of intensity $I$, and $c$ is a measure of the state of adaptation, $f_{1}$ and $f_{2}$ being any functions, then by arguments given in the paper cited

$$
N=N_{0}+f_{1}(c) I^{r / k}
$$

where $N_{0}$ is a constant, and $r / k$ is the ratio of $\Delta N / N$ to $\Delta I / I, \Delta N / N$ being the physiological equivalent of the Weber-Fechner fraction. The above relationship implies a linearity between $\log \left(N-N_{0}\right)$ and $\log I$, and electrophysiological studies show that this is approximately true if $N$ is the number of nerve impulses per second per nerve fibre.

I am grateful to Gregory and Cane for having directed my attention (in a private communication) to a slight error in the mathematics of my paper ${ }^{2}$; the conclusions of the paper are unaffected, but the matter will be discussed in a short note, which $I$ hope to publish as a correction to the original paper.

\section{R. W. G. Hunt}

Research Laboratories,

Kodak Limited, Wealdstone, Harrow, Middlesex. July 20.

${ }^{1}$ Gregory, R. L., and Cane, Violet, Nature, 178, 1272 (1955).

${ }^{2}$ Hunt, R. W. G., J. Photo. Sci., 1, 149 (1953). 